\title{
Efek Farmakologi Suspensi Biji Lada Hitam (Piper nigrum L.) dan Piperin Terhadap Tekanan Darah Kucing Teranestesi
}

\author{
Dian Ermawati \\ Fakultas Ilmu Kesehatan Universitas Muhammadiyah Malang \\ email : dianerma@yahoo.com
}

\begin{abstract}
ABSTRAK
Hipertensi atau tekanan darah tinggi adalah salah satu penyakit degeneratifyang mempunyai risiko penyebab kematian yang cukup tinggi. Menurut berbagai penelitian didapatkan prevalensi penyakit hipertensi mencapai 15-20\%. Untuk mengatasinya, akhir-akhir ini orang cenderung untuk kembali memakai produk-produk alami. Biji lada hitam (Piper nigrum L.) yang mempunyai kandungan pedas yaitu piperin dengan kadar yang relatif besar sekitar 5-9\% digunakan masyarakat pemakai obat tradisional untuk mengobati penyakit tekanan darah tinggi. Untuk itu diperlukan pembuktian secara ilmiah apakah terdapat daya hipotensif biji lada hitam dan piperin terhadap tekanan darah kucing teranestesi. Dalam penelitian ini hewan uji kucing dibagi dalam 5 kelompok yaitu kelompok I suspensi biji lada hitam dosis $5 \%$, kelompok II suspensi biji lada hitam dosis $20 \%$, kelompok II suspensi biji lada hitam dosis $40 \%$, kelompok IV kontrol negatif CMC Na 0,5\% dan kelompok V piperin dosis $5 \%$. Pemberian larutan uji secara intagastrik, dilakukan saat tekanan darah stabil (dianggap waktu/t=0). Pengukuran tekanan darah dilakukan sebelum dan sesudah pemberian bahan uji yaitu pada menit keo, 15,30,45,60,75,90,105, dan 120.Analisis data menggunakan uji deskriptif, uji Kruskal Wallis, Uji Mann Whitney dan uji Split -plot. Hasil penelitian menunjukkan pemberian suspensi biji lada hitam yang diberikan pada kucing yang teranestesi menunjukkan efek hipotensif. Lada hitam dosis $5 \%$ menunjukkan penurunan tekanan darah yang sesuai dengan pengobatan hipertensi dengan durasi dari menit ke 0 sampai menit ke 120. Lada hitam dosis $20 \%$ memberikan penurunan tekanan darah terbesar pada menit ke-60 sebesar 45,67\%.
\end{abstract}

Kata kunci : Biji lada hitam, kucing, hipotensif

\section{PENDAHULUAN}

Hipertensi atau tekanan darah tinggi adalah salah satu penyakit degeneratif yang mempunyai risiko penyebab kematian yang cukup tinggi. Menurut berbagai penelitian didapatkan prevalensi penyakit hipertensi mencapai $15-20 \%$ (Darmojo,2001). Hipertensi ini dapat mengakibatkan stroke (adanya kematian jaringan di daerah yang tidak mendapat aliran darah) yang dapat membawa kelumpuhan atau kematian mendadak (Mursito,2001).

Untuk mengatasinya, akhirakhir ini orang cenderung untuk kembali memakai produk-produk alami. Kemajuan teknologi dan ilmu pengetahuan ternyata tidak begitu saja menggeser kepercayaan orang terhadap pengobatan dengan ramuan- ramuan bahan alam (tumbuhan, mineral, dan hewan) yang berkhasiat atau diperkirakan berkhasiat untuk suatu pengobatan berdasarkan pengalaman yang turun temurun.

Sampai saat ini pemakaian obat tradisional terutama lebih didasarkan pada pengalaman atau dugaan-dugaan yang diwariskan secara turun temurun ,belum didasarkan pada hasil penelitian dan percobaan yang seksama. Contohnya biji lada hitam yang mempunyai kandungan pedas yaitu piperin dengan kadar yang relatif besar sekitar 5-9\% digunakan masyarakat pemakai obat tradisional untuk mengobati penyakit tekanan darah tinggi. Oleh karena itu untuk meningkatkan mutu pelayanan kesehatan terhadap penderita tekanan darah tinggi, pengembangan dan penelitian biji 
lada hitam sebagai obat antihipertensi perlu dilakukan agar mempunyai pijakan yang kuat dan benar-benar dapat dipertanggungjawabkan.

Pada beberapa pustaka tentang obat tradisional, juga disebutkan bahwa biji lada hitam mempunyai khasiat sebagai antihipertensi. Hal inilah yang ingin dibuktikan kebenarannya secara ilmiah, apakah suspensi biji lada hitam dan piperin yang merupakan kandungan pedas terbesar dalam biji tersebut dapat menurunkan tekanan darah kucing teranestesi dan dosis yang diperlukan untuk menurunkan tekanan darah kucing teranestesi tersebut.

Menurut Jhon et al., (1988), kucing digunakan untuk hewan uji karena kucing mempunyai persamaan anatomik dan fisiologik sistem kardiovaskuler dengan manusia disamping anjing dan kera. Selain itu besar dan bobot kucing memadai sehingga dapat dibedah dan dipasang alat pencatat tekanan darah secara tepat dan mudah.Juga kucing mudah dianestesi unutk jangka waktu yang lama dan tekanan darh yang bagus biasanya dapat dipertahankan.

\section{METODOLOGI PENELITIAN Bahan}

Bahan uji yang digunkan adalah lada hitam (Piper nigrum L.) yang berasal dari pasar Purworejo yang disuplai dari Sumatera dan piperin standard buatan E.Merck.

\section{Hewan uji}

Hewan uji yang digunakan adalah kucing jantan atau betina dengan berat badan $1,8-3,0 \mathrm{~kg}$

\section{Alat}

Seperangkat alat operasi (Solingen, Germany),Kimograf Kertas angus (INCO India),Manometer air raksa

\section{Tahapan pelaksanaaan}

\section{Penyiapan Suspensi Biji Lada Hitam}

Sebagai Bahan Uji

Penyiapan sediaan dilakukan dengan mengumpulkan simplisia biji lada hitam. Ditebarkan setipis mungkin pada wadah dan dikeringkan dalam oven bersuhu $40^{\circ} \mathrm{C}-60^{\circ} \mathrm{C}$. Bahan ditumbuk dan diayak dengan ayakan no 55. Sediaan dibuat dengan cara mensuspensikan serbuk biji lada hitam dalam akuades dengan menggunakan $\mathrm{CMC} \mathrm{Na} \mathrm{0,5}$
$\%$ sebagai suspending agent.

2. Penyiapan Piperin Sebagai Bahan Uji Piperin yang digunakan sebagai bahan uji adalan piperin standard buatan pabrik (E.Merck) yang disuspendikan dalam akuades CMC Na 0,5\%.

3. Pengujian daya hipotensif

\subsection{Pengelompokan hewan uji}

Dalam penelitian ini digunakan hewan uji kucing jantan dan betina sebanyak 15 ekor dengan berat badan rata-rata $1,8-3,0 \mathrm{~kg}$. Kemudian dibagi dalam 5 kelompok yaitu kelompok I suspensi biji lada hitam dosis 5 $\%$, kelompok II suspensi biji lada hitam dosis $20 \%$, kelompok II suspensi biji lada hitam dosis $40 \%$, kelompok IV kontrol negatif CMC Na 0,5\% dan kelompok $\mathrm{V}$ piperin dosis $5 \%$. Masing-masing kelompok terdiri atas 3 ekor kucing jantan atau betina.

\subsection{Persiapan Hewan Uji}

Kucing ditimbang terlebih dahulu, kemudian dianestesi dengan eter. Setelah itu diterlentangkan di meja operasi dengan mengikat keempat kakinya pada meja tersebut. Anestesi dilanjutkan dengan pemberian alfa kloralose dalam larutan boraks $5 \%$ dengan dosis $60-90 \mathrm{mg} / \mathrm{kg} \mathrm{BB}$. Kemudian ditambahkan heparin (lebih kurang $0,5 \mathrm{ml}$ ) untuk mencegah penjendalan darah dan didorong dengan larutan fidiologis $(\mathrm{NaCl} \quad 0,9 \%)$ kira-kira $1 \mathrm{ml}$. Kloralose, heparindan larutan fisiologis diberikan secara intravena yaitu melalui pembuluh darah balik salah satu kaki depan (vena mediana cubits), setelah itu dilakukan trakeatomi. Kanula trakea dimasukkan ke dalam trakea untuk menghindari tersumbatnya saluran pernafasan oleh lendir selama pembiusan.

\subsection{Perekaman data percobaan}

Arteri carotis comunis disobek sedikit kemudaian kanula kecil yang telah berisi larutan $\mathrm{NaCl}$ 0,9\% dimasukkan ke arteria carotis comunis tersebut. Kanula tersebut selanjutnya dihubungkan dengan manometer air raksa. Tekanan darah sistemik $(\mathrm{mmHg})$ direkam pada kertas angus yang dipasang pada kimograf. Tekanan darah sistemik kucing ditunggu hingga stabil. Setelah stabil(dianggap waktu/t=0), diberikan suspensi biji lada hitam, piperin dan kontrol negatif. Pengukuran tekanan darah dilakukan 
sebalum dan sesudah pemberian bahan uji yaitu pada menit ke $0,15,30,45,60,75,90,105,120$. Setelah pengukuran tekanan darah selesai, kertas angus dilepaskan dari kimograf tabung ganda kemudian dicelupkan ke dalam larutan sirlak alam spiritus sehingga data yang diperoleh pada kertas angus tidak hilang.

4. Analisa Hasil

1. Analisa Deskriptif

Data Pengukuran tekanan darah yang diperoleh selanjutnya dihitung prosentasi penurunannya dengan menggunakan persamaan

$\%$ Penurunan Tekanan Darah $=\frac{\text { Po-P1 }}{\text { Po }} \times 100 \%$

Keterangan $:$ Po $=$ tekanan darah sistemik pada menit ke- 0

P1 = Tekanan darah sistemik pada menit ke60

2. Statistika non parametrik metode Kruskal Wallis dengan mengubah data penurunan tekanan darah $(\mathrm{mmHg}) \mathrm{ke}$ dalam bentuk AUC (Area Uneer Curve), jika terdapat perbedaan yang bermakna maka dilanjutkan dengan uji Mann Whitney

Uji multivarian menggunakan metode split-plot dengan mengolah data penurunan tekanan darah langsung.

\section{HASIL DAN PEMBAHASAN}

Pada uji deskriptif yang dianggap sebagai penurunan tekanan darah maksimal yaitu pada menit ke-60 setelah perlakuan. Hasilnya dapat dilihat pada Tabel 1.

Dari hasil lima kelompok dosis yang diuji yaitu suspensi biji lada hitam dosis 5\% memberikan persentase penurunan sebesar
$36,91 \%$,dosis $20 \%$ sebesar $45,67 \%$, dosis $40 \%$ sebesar $39,35 \%$, piperin dosis $5 \%$ sebesar 37,19\% dan kontrol negatif sebesar $29,23 \%$. Penurunan tertinggi ditunjukkan oleh lada hitam dosis $20 \%$.

Analisa statistik selanjutnya menggunakan statistika non parametrik metode Kruskal Wallis dengan mengubah data penurunan tekanan darah $(\mathrm{mmHg}) \mathrm{ke}$ dalam bentuk AUC (Area Under Curve), jika terdapat perbedaan yang bermakna maka dilanjutkan dengan uji Mann Whitney.

Berdasarkan analisa data secara nonparametrik dengan Kruskal Wallis memberikan nilai sebesar $0,023(p<0,05)$. Ini menunjukkan terjadi perbedaan yang bermakna antar kelompok dosis perlakuan. Selanjutnya dilakukan uji Mann-Whitney. Pada uji ini terjadi perbedaan marjinal $(\mathrm{p}=0,05)$ pada lada hitam dosis $5 \%$ dengan kontrol negatif, lada hitam dosis $20 \%$ dengan kontrol negatif, lada hitam dosis 40 $\%$ dengan kontrol negatif. Hal ini menggambarkan bahwa lada hitam cenderung mempunyai daya hipotensif, tapi karena adanya simpangan baku yang besar menyebabkan perbedaan penurunan tekanan darah antar lada hitam dengan kontrol negatif menjadi marjinal. Seharusnya lada hitam dosis $5 \%, 20 \%$ dan $40 \%$ menunjukkan perbedaan yang bermakna terhadap kontrol negatif. Perbedaan marjinal juga terjadi antara lada hitam dosis $5 \%$, lada hitam dosis $20 \%$, lada hitam dosis $40 \%$ dengan piperin dosis $5 \%$. Diharapkan piperin dosis $5 \%$ menunjukkkan perbedaan yang tidak bermakna dengan lada hitam dosis $5 \%$ yang artinya piperin yang terkandung dalam lada hitam dosis $5 \%$ relatif sama dengan piperin dosis $5 \%$ yang menunjukkan efek hipotensif. Perbedaan yang marjinal ini menunjukkan

Tabel 1. Hasil uji deskriptif penurunan tekanan darah

\begin{tabular}{|l|l|c|}
\hline No & Perlakuan & Penurunan tekanan darah (\%) \\
\hline 1. & Kontrol negatif CMC Na 0,5\% & 29,23 \\
\hline 2. & Piperin dosis 5\% & 37,19 \\
\hline 3. & Lada Hitam dosis 5\% & 36,91 \\
\hline 4. & Lada hitam dosis $20 \%$ & 45,67 \\
\hline 5. & Lada hitam dosis $40 \%$ & 39,35 \\
\hline
\end{tabular}


Tabel 2. Tekanan Darah Kucing perlakuan dosis lada hitam $5 \%$

\begin{tabular}{|c|c|c|c|c|c|c|c|c|c|c|c|c|}
\hline \multirow[b]{3}{*}{ No } & \multicolumn{9}{|c|}{ Tekanan Darah Kucing (mmHg) } & \multirow[b]{3}{*}{ AUC } & \multirow[b]{3}{*}{ Rata2 } & \multirow[b]{3}{*}{ SD } \\
\hline & \multicolumn{9}{|c|}{ Sesudah Perlakuan (menit) } & & & \\
\hline & 0 & 15 & 30 & 45 & 60 & 75 & 90 & 105 & 120 & & & \\
\hline Kucing I & 150 & 140 & 105 & 95 & 90 & 83 & 83 & 83 & 84 & 11940 & 12825 & 992,351 \\
\hline Kucing II & 133 & 130 & 120 & 110 & 95 & 110 & 115 & 120 & 120 & 13898 & & \\
\hline Kucing III & 155 & 145 & 120 & 95 & 85 & 85 & 90 & 95 & 100 & 12638 & & \\
\hline
\end{tabular}

Tabel 3. Tekanan Darah Kucing perlakuan dosis lada hitam $20 \%$

\begin{tabular}{|c|c|c|c|c|c|c|c|c|c|c|c|c|}
\hline \multirow[b]{3}{*}{ No } & \multicolumn{9}{|c|}{ Tekanan Darah Kucing (mmHg) } & \multirow[b]{3}{*}{ AUC } & \multirow[b]{3}{*}{ Rata2 } & \multirow[b]{3}{*}{$S D$} \\
\hline & \multicolumn{9}{|c|}{ Sesudah Perlakuan (menit) } & & & \\
\hline & 0 & 15 & 30 & 45 & 60 & 75 & 90 & 105 & 120 & & & \\
\hline Kucing I & 150 & 132 & 125 & 120 & 113 & 115 & 118 & 113 & 120 & 14565 & & \\
\hline Kucing II & 130 & 108 & 95 & 92 & 90 & 87 & 90 & 90 & 90 & 11430 & & \\
\hline Kucing III & 155 & 130 & 115 & 110 & 105 & 95 & 95 & 95 & 95 & 13050 & 13015 & 2091,963 \\
\hline
\end{tabular}

Tabel 4. Tekanan Darah Kucing perlakuan dosis lada hitam $40 \%$

\begin{tabular}{|c|c|c|c|c|c|c|c|c|c|c|c|c|}
\hline \multirow[b]{3}{*}{ No } & \multicolumn{9}{|c|}{ Tekanan Darah Kucing (mmHg) } & \multirow[b]{3}{*}{ AUC } & \multirow[b]{3}{*}{ Rata2 } & \multirow[b]{3}{*}{ SD } \\
\hline & \multicolumn{9}{|c|}{ Sesudah Perlakuan (menit) } & & & \\
\hline & 0 & 15 & 30 & 45 & 60 & 75 & 90 & 105 & 120 & & & \\
\hline Kucing I & 117 & 105 & 82 & 73 & 65 & 65 & 68 & 70 & 73 & 9345 & & \\
\hline Kucing II & 110 & 90 & 90 & 85 & 82 & 82 & 81 & 82 & 83 & 10328 & & \\
\hline Kucing III & 135 & 98 & 70 & 65 & 70 & 75 & 75 & 80 & 80 & 9608 & 9760 & 508,897 \\
\hline
\end{tabular}

Tabel 5. Tekanan Darah Kucing perlakuan kontrol negatif CMC Na 0,5\%

\begin{tabular}{|c|c|c|c|c|c|c|c|c|c|c|c|c|}
\hline \multirow[b]{3}{*}{ No } & \multicolumn{9}{|c|}{ Tekanan Darah Kucing (mmHg) } & \multirow[b]{3}{*}{ AUC } & \multirow[b]{3}{*}{ Rata2 } & \multirow[b]{3}{*}{ SD } \\
\hline & \multicolumn{9}{|c|}{ Sesudah Perlakuan (menit) } & & & \\
\hline & 0 & 15 & 30 & 45 & 60 & 75 & 90 & 105 & 120 & & & \\
\hline Kucing I & 130 & 115 & 88 & 75 & 70 & 75 & 78 & 78 & 80 & 10260 & & \\
\hline Kucing II & 152 & 125 & 85 & 85 & 65 & 70 & 78 & 86 & 90 & 10725 & & \\
\hline Kucing III & 113 & 105 & 100 & 83 & 75 & 65 & 55 & 70 & 70 & 9667 & 10217 & 530,289 \\
\hline
\end{tabular}

Tabel 6. Tekanan Darah Kucing perlakuan dosis piperin 5\%

\begin{tabular}{|c|c|c|c|c|c|c|c|c|c|c|c|c|}
\hline \multirow[b]{3}{*}{ No } & \multicolumn{9}{|c|}{ Tekanan Darah Kucing (mmHg) } & \multirow[b]{3}{*}{ AUC } & \multirow[b]{3}{*}{ Rata2 } & \multirow[b]{3}{*}{ SD } \\
\hline & \multicolumn{9}{|c|}{ Sesudah Perlakuan (menit) } & & & \\
\hline & 0 & 15 & 30 & 45 & 60 & 75 & 90 & 105 & 120 & & & \\
\hline Kucing I & 105 & 95 & 82 & 82 & 82 & 78 & 80 & 82 & 82 & 10118 & & \\
\hline Kucing II & 96 & 65 & 55 & 55 & 45 & 42 & 45 & 55 & 55 & 6458 & & \\
\hline Kucing III & 70 & 60 & 50 & 50 & 45 & 41 & 41 & 40 & 40 & 5760 & 7455 & 2340,761 \\
\hline
\end{tabular}


Tabel 7. Hasil uji Split-plot

\begin{tabular}{|l|l|l|l|l|l|}
\hline Waktu & $\begin{array}{l}\text { Lada hitam } \\
\text { dosis } 5 \%\end{array}$ & $\begin{array}{l}\text { Lada hitam } \\
\text { dosis } 5 \%\end{array}$ & $\begin{array}{l}\text { Lada hitam } \\
\text { dosis 5\% }\end{array}$ & $\begin{array}{l}\text { Lada hitam } \\
\text { dosis 5\% }\end{array}$ & $\begin{array}{l}\text { Lada hitam } \\
\text { dosis 5\% }\end{array}$ \\
\hline 0 & S & NS & NS & NS & NS \\
\hline 15 & S & S & S & S & S \\
\hline 30 & S & S & S & S & S \\
\hline 45 & S & NS & S & S & S \\
\hline 60 & S & NS & NS & S & NS \\
\hline 75 & S & NS & NS & S & NS \\
\hline 90 & S & NS & NS & S & NS \\
\hline 105 & S & NS & NS & NS & NS \\
\hline 120 & S & NS & NS & NS & NS \\
\hline
\end{tabular}

Keterangan:

$\mathrm{S}=$ bermakna

Dikatakan bermakna apabila 2 atau lebih dari kelompok dosis menunjukkan $\mathrm{p}<0,05$

NS = tidak bermakna

Dikatakan tidak bermakna apabila 1 kelompok dosis menunjukkan $\mathrm{p}<0,05$

kemungkinan adaanya zat lain dalam lada hitam yang mempunyai daya hipotensif.

Pada uji Split-plot memberikan hasil sebagai berikut : kelompok lada hitam dosis $5 \%$ menunjukkan hasil yang bermakna dari menit ke-0 sampai menit ke-120, kelompok lada hitam dosis $20 \%$ menunjukkan hasil yang bermakna dari menit ke-15 sampai ke30 , kelompok lada hitam dosis $40 \%$ menunjukkan hasil yang bermakna dari menit ke 15 sampai ke-45, kelompok kontrol negatif menunjukkan hasil yang bermakna dari ment ke-15 sampai menit ke-90, dan kelompok piperin dosis $5 \%$ menunjukkan hasil yang bermakna dari menit ke 15 sampai menit ke-45. Hasil uji split-plot dapat dilihat pada tabel 2.

Berdasarkan uji deskriptif pada menit ke-60 penurunan tekanan darah terbesar terjadi pada lada hitam dosisi $20 \%$, sedangkan pada uji split-plot dosis $20 \%$ memberikan hasil yang bermakna selama 15 menit sehingga mempunyai durasi pendek. Namun hal ini tidak diinginkan dalam pengobatan hipertensi karena selain durasinya pendek, profil grafiknya menunjukkan penurunan tekanan darah yang tajam. Sebaliknya penurunan tekanan darah yang terjadi berlangsung secara bertahap.Durasi yang panjang ini sesuai dengan metode pengobatan hipertensi. Menurut Suhardjono (2001) penurunan tekanan darah secara bertahap untuk mengurangi kemungkinan terjadinya gejala iskemia, hipotensi ortostatik dan dianjurkan obat yang bekerja jangka panjang.

Uji split - pot pada lada hitam dosis $20 \%$ dan $40 \%$ mempunyai onset yang lebih lama yaitu 15 menit dibandingkanan lada hitam dosis $5 \%$. Hal ini kemungkinan terjadi akibat adanya ikatan zat aktif lada hitam 5 $\%$ dengan reseptor yang menimbulkan efek optimum sedangkan pada lada hitam dosis $20 \%$ dan $40 \%$ terjadi penjenuhan ikatan zat aktif dan reseptor yang dapat menurunkan efek yang terjadi selama 15 menit.

\section{KESIMPULAN}

1. Pemberian suspensi biji lada hitam yang diberikan secara intragastrik pada kucing yang teranestesi menunjukkan efek hipotensif.

2. Lada hitam dosis $5 \%$ menunjukkan penurunan tekanan darah yang sesuai dengan pengobatan hipertensi dengan durasi dari menit ke-0 sampai menit ke-120

3. Lada hitam dosis $20 \%$ memberikan penurunan tekanan darah terbesar pada menit ke-60 sebesar 45,67\%

\section{DAFTAR PUSTAKA}

Darmojo, B.,2001,Mengamati Perjalanan Epidemiologi di Indonesia,MEDIKA, 
No 7 tahun ke XXXVII, Juli 2001, hal 442-448

$\mathrm{J} \quad \mathrm{h}$

o $n \quad, \quad B$

Smith,B.V.,Mangkuwidjojo,S.,1988, Pemeliharaan, Pembiakan dan Penggunaan Hewan Percobaan di Daerah Tropis, Universitas Indonesia Press Jakarta,hal 149-187

Mursito, Bambang, 2001,Sehat di Usia Lanjut dengan Ramuan Tradisional, Penebar Swadaya:Jakarta, hal 2829,77-78

Rismunandar, 2000, Lada Budidaya dan Tata Niaganya, Penebar Swadaya:Jakarta

Suhardjono, 2001, Kiat Pengobatan Hipertensi pada Usia Lanjut, www.interna.fk.ui.ac.id 